Abstracta Iranica Abstranica

Revue bibliographique pour le domaine irano-aryen

Volume 27 | 2006

Comptes rendus des publications de 2004

Late Achaemenid and Hellenistic Babylon. OLA, 136, 2004, 385 p. et 9 pl. de copies de textes cunéiformes.

Astrid Nunn

(2) OpenEdition

Journals

Édition électronique

URL : http://journals.openedition.org/abstractairanica/5680

DOI : 10.4000/abstractairanica.5680

ISSN : 1961-960X

Éditeur :

CNRS (UMR 7528 Mondes iraniens et indiens), Éditions de l'IFRI

Édition imprimée

Date de publication : 15 mai 2006

ISSN : 0240-8910

Référence électronique

Astrid Nunn, «Late Achaemenid and Hellenistic Babylon. OLA, 136, 2004, 385 p. et 9 pl. de copies de textes cunéiformes. », Abstracta Iranica [En ligne], Volume 27 | 2006, document 60, mis en ligne le 02 janvier 2007, consulté le 25 septembre 2020. URL : http://journals.openedition.org/abstractairanica/ 5680 ; DOI : https://doi.org/10.4000/abstractairanica.5680

Ce document a été généré automatiquement le 25 septembre 2020.

Tous droits réservés 


\title{
Late Achaemenid and Hellenistic Babylon. OLA, 136, 2004, 385 p. et 9 pl. de copies de textes cunéiformes.
}

\author{
Astrid Nunn
}

1 Le sujet de cette thèse de doctorat à l'Université Catholique de Louvain était à l'origine l'époque hellénistique à partir d'Alexandre le Grand. Mais l'A. a vite réalisé qu'il comprendrait mieux cette période s'il commençait son étude un peu avant. Bien évidemment la conquête d'Alexandre ne changea pas tout du jour au lendemain. Au contraire! Néanmoins l'accent est mis sur la Babylone hellénistique. La reconstruction de son histoire repose surtout sur des sources cunéiformes qui proviennent presque toutes du temple Esagil. Mais l'A. recourt aussi aux ostraca et aux inscriptions grecques (pp. 39-41), aux inscriptions palmyréennes, au Talmud babylonien (p.51) et aux monnaies (pp. 44-47). L'étude débute par la topographie achéménide et hellénistique (pp. 55-98 murailles, routes, canaux, temples, jardins suspendus), basée sur les vestiges archéologiques (pp. 8-12), la description dans les sources classiques (pp. 47-51) ainsi que sur le matériel cunéiforme très varié qui consiste en textes légaux, en contrats de mariage, reçus de paiement, textes de propriété foncière, en contrats d'apprentissage, en nombreuses listes de ration, en listes de dépenses du temple, en textes historiques, en Chroniques, en prophéties, en textes sur la topographie, en textes littéraires et religieux, en rituels, incantations, lamentations, hymnes, calendrier, omina, en textes astrologiques, astronomiques, mathématiques et médicaux (pp. 13-39). Le rôle politique de Babylone (pp.99-192) ainsi que ses institutions socio-économiques, religieuses, familiales et culturelles (pp.193-303) font l'objet du chapitre suivant. Un dernier chapitre traite de l'héritage que nous a laissé la Babylone hellénistique (pp. 304-316). Ce livre très clair est un excellent ouvrage de référence pour la Babylone tardive. 
INDEX

Thèmes : 3.2.1. Elam

\section{AUTEURS}

ASTRID NUNN

Université de Munich 